\begin{tabular}{|c|c|c|c|}
\hline Article Info & RESEARCH ARTICLE & ARAŞTIRMA MAKALESİ & \\
\hline Title of Article & $\begin{array}{l}\text { Assessment of Edu } \\
\text { Nature Conservatic } \\
\text { Example of Second }\end{array}$ & $\begin{array}{l}\text { cational Changes in } \\
\text { n Approaches in the } \\
\text { ary School Students }\end{array}$ & \\
\hline $\begin{array}{l}\text { Corresponding } \\
\text { Author }\end{array}$ & $\begin{array}{l}\text { Sibel MANSUROĞLU } \\
\text { Akdeniz Üniversitesi, Mimarlık } \\
\text { smansur@akdeniz.edu.tr }\end{array}$ & akültesi, $\quad$ Peyzaj $\quad$ Mimarlığı $\quad$ Bölümü, & 7 \\
\hline $\begin{array}{l}\text { Received Date } \\
\text { Accepted Date }\end{array}$ & $\begin{array}{l}27.04 .2021 \\
26.05 .2021\end{array}$ & & \\
\hline DOI Number & https://doi.org/10.35674/kent.929040 & & \\
\hline Author / Authors & $\begin{array}{l}\text { Sibel MANSUROĞLU } \\
\text { Tuğba KELEŞ } \\
\text { Veysel DAĞ }\end{array}$ & $\begin{array}{l}\text { ORCID: 0000-0003-3451-3069 } \\
\text { ORCID: 0000-0002-8186-6863 } \\
\text { ORCID: 0000-0002-2111-7756 }\end{array}$ & \\
\hline How to Cite & $\begin{array}{l}\text { Mansuroğlu, S., Keleş, T. and Dağ, V. ( } 20 \\
\text { Bağlı Değişimlerin Ortaokul Öğrenc } \\
\text { Akademisi, Volume, 14, Issue 2, 347-360 }\end{array}$ & $\begin{array}{l}\text { 1). Doğa Koruma Yaklaşımlarında Eğitime } \\
\text { leri Ö̈rneğinde Değerlendirilmesi, Kent }\end{array}$ & $\begin{array}{l}\text { Kent Akademisi } \\
\text { Urban Academy }\end{array}$ \\
\hline
\end{tabular}

\title{
Doğa Koruma Yaklaşımlarında Eğitime Bağlı Değişimlerin Ortaokul Öğrencileri Örneğinde Değerlendirilmesi
}

Sibel MANSUROĞLU ${ }^{1}$

Tuğba KELEŞ ${ }^{2}$

Veysel DAĞ ${ }^{3}$

\begin{abstract}
:
Nature conservation areas, which are most affected by environmental problems and play an active role in combating these problems, become more important day by day. All individuals have various responsibilities to protect nature and leave a liveable world to future generations. It is reported by many researchers that education given at an early age is important for the protection of natural areas and prevention of their problems. The aim of this study is to determine nature conservation approaches in the sample of secondary school students and to evaluate their changes depending on education. In order to determine the knowledge level and awareness of the students of Ayten Çağıran Secondary School in Antalya, Konyaaltı district, about nature protection, an on-site survey method was applied with standard forms. The educational presentation was prepared by evaluating the applied questionnaire forms, and a training presentation was made to the students on nature conservation, suitable for the age groups of the students. The same questionnaire was applied again, after the presentation. Survey forms applied before and after the training presentation were statistically analysed. After the presentation of the education, positive changes were determined in the students' approach to the subject depending on their gender and class level. At the end of the study, it was determined that educational work on nature conservation given by experts outside the school had an impact on students.
\end{abstract}

KEYWORDS: Nature Education, Nature Conservation, Environmental Consciousness, Environmental Attitude, Landscape Architecture.

\footnotetext{
${ }^{1}$ Prof. Dr., Akdeniz Üniversitesi, Mimarlık Fakültesi, Peyzaj Mimarlığı Bölümü, smansur@akdeniz.edu.tr

${ }^{2}$ Peyzaj Yüksek Mimarı, Akdeniz Üniversitesi, Fen Bilimleri Enstitüsü, Peyzaj Mimarlığı Anabilim Dalı, tugbaolcerr@gmail.com

${ }^{3}$ Araş. Gör., Pamukkale Üniversitesi, Mimarlık ve Tasarım Fakültesi, Peyzaj Mimarlığı Bölümü, veyseldag@ windowslive.com
} 


\section{ÖZ:}

Çevre sorunlarından en fazla etkilenen ve bu sorunlarla mücadelede etkin rol oynayan doğa koruma alanları gün geçtikte daha fazla önem kazanmaktadır. Doğanın korunması ve gelecek nesillere yaşanılabilir bir dünyanın bırakılması için tüm bireylere çeşitli sorumluluklar düşmektedir. Doğal alanların korunması ve sorunlarının önlenmesi için erken yaşta verilen eğitimin önemli olduğu birçok araştıııcı tarafından bildirilmektedir. Bu çalışmanın amacı ortaokul öğrencileri örneğinde doğa koruma yaklaşımlarının belirlenmesi ve eğitime bağlı değissimlerinin değerlendirilmesidir. Antalya, Konyaaltı ilçesi Ayten Çağıran Ortaokulu öğrencilerinin doğa koruma konusunda bilgi düzeyi ve farkındalıklarının belirlenmesinde standart formlarla yerinde anket yöntemi uygulanmıştır. Uygulanan anket formları değerlendirilerek eğitim sunumu hazırlanmış ve öğrencilere doğa koruma konusunda yaş gruplarına uygun bir eğitim sunumu yapılmıştır. Sunum sonrası aynı anket formu tekrar uygulanmıştır. Eğitim sunumu öncesi ve sonrası uygulanan anket sonuçları istatistiksel analizlerle değerlendirilmiştir. Analiz sonuçları, eğitim sunumu sonrası öğrencilerin cinsiyet ve sınıf düzeylerine bağlı olarak konuya yaklaşımlarında olumlu yönde değişimler saptandığını göstermiştir. Çalışma sonunda okul dışında uzmanlar tarafindan verilen doğa koruma konusundaki eğitim çalışmalarının, öğrenciler üzerinde etkili olduğu tespit edilmiştir.

ANAHTAR KELİMELER: Doğa Eğitimi, Doğa Koruma, Çevre Bilinci, Çevresel Tutum, Peyzaj Mimarlığı.

\section{"Doğa Koruma Yaklaşımlarında Eğitime Bağlı Değişimlerin Ortaokul Öğrencileri Örneğinde Değerlendirilmesi”}

\section{GİRIŞ:}

Doğa koruma, insan sağlığı ve yaşamın garantisi için, doğada yaşayan bitki ve hayvan türlerinin varllğı, onların yetişme ve yaşam ortamları ile belli ölçütler ışığında korumaya değer bulunan doğa parçalarının ve doğal elemanların korunması olarak tanımlanmaktadır. Doğaya yapılan müdahaleler ve baskılar sonucu doğal faktörler üzerindeki önemli değişiklikler, günümüzde insan hayatını tehdit eder duruma gelmiştir. Doğadaki bu olumsuz etkiler ve sonuçları modern teknoloji ile önlenemediği gibi kısa zamanda doğanın kendi kendini yenilemesi ile eski haline dönüştürülebilmesi de olası değildir (Yücel, 2010). Sera etkisi, asit yağmurları, su kaynaklarının tükenmesinin yanı sıra, orman tahribatı, kirlilik (toprak, su, hava), iklim değişikliği, biyolojik çeşitliliğin azalması, enerji kaynaklarının azalması ve diğer çevresel zararlar küresel bir çevre krizinin yaşandığının göstergeleridir. Bu çevresel sorunların büyük bir bölümü insanların sonsuz ve sınırlandırılmayan ihtiyaçları için sınırlı olan doğal kaynakları hızla tüketmesinin bir sonucu olarak görülmektedir. Doğal alanlarda yaşanan sorunlara, insanların doğal alanlar ve bunların korunması konusundaki bilgi düzeylerinin yetersizliği de eklendiğinde, bu alanların zarar görmesi kaçınılmaz olmaktadır. Ancak insanların tutum ve davranışları değiştirilerek bu çevresel sorunları ve etkileri azaltılabilir (Norris ve Juliet, 2016). Doğanın korunması ve gelecek nesillere yaşanılabilir bir dünyanın bırakılması için tüm bireylere çeşitli sorumluluklar düşmektedir. Ortaya çıkan çevresel sorunların önlenmesi ve etkisinin azaltılması için atılabilecek stratejik ve sürdürülebilir adımlardan biri de eğitimdir. Azhar ve ark. (2015)'e göre eğitim, değerleri içselleştirmek ve inançları, bilgileri ve becerileri dönüştürmek için en uygun araç olarak kabul edilmektedir (Istiqomah ve ark., 2020). Monroe ve ark. (2008) ise çevre eğitimini birçok meslek disiplini ile ilişkili bir uzmanlık alanı, yaklaşım metodu, araç ve felsefe olarak kabul ederken, en temel hali ile çevre hakkında ve çevre için bilgi edinme olarak tanımlamaktadırlar. Araştırmacılar çevre eğitiminin çok çeşitli öğretim yöntemleri, konuları, izleyicileri ve eğitimcileri kapsadığını ifade etmektedirler. Çevre eğitimi, diğer uygulamalarda olduğu gibi uzun vadede sosyal değişim ve gelişme kapasitesini arttırmayı hedeflerken, kısa ve orta vadede beklenen gelişmeleri/ilerlemeyi ölçme sorunu ile de karşı karşıyadır (Fien ve ark., 2001).

Bir organizasyon olarak okul eğitim sistemlerinin, çevre (özellikle tarihi çevre arasında) ile bağlantı kurarak gerekli bilgi ve tutumların oluşmasına ve gelişmesine katkı sağladığı kabul edilmektedir (Campbell ve Robottom, 2004). Ancak uygulamalarda yaşanan sorunlar mevcut uygulamaların doğadan kopukluğu pekiştirdiğini göstermektedir (Reis ve ark., 2018). Oysa çevre eğitiminin genel eğitim içerisinden ayrı düşünülmesi sosyal ve ekolojik olarak eğitim hedeflerine aykırı bir durum teşkil etmektedir (Gruenewald, 2004). Bu durum öğretmenler ve öğrencilerin genellikle kısa süreli çevresel eğitim programlarını teşvik etmek ve ilerletmek konusunda sorun yaşamalarına yol açmaktadır (Reis ve Guimaraes-Iosif, 2012). Kaçkar Dağları Milli Parkı örneğinde, çeşitli meslek gruplarının katılımı ile yapılan eğitimlerde doğaya saygıll, onu anlayabilen, katılımcı, sorunların farkında olan ve çözüm üretebilen bireylerin yetiştirilmesine önem verilmesi gerektiği vurgulanmıştır (Kalender, 2010). Türkiye'nin farklı kentlerinde ilgili 
bakanlığın (T.C. Tarım ve Orman Bakanlığı) yerel teşkilatlarında görev yapan uzmanlar tarafından ortaokul ve lise öğrencilerine yönelik doğa ve biyolojik çeşitliliğin korunması konulu eğitimler verildiği basında çıkan haberlerde yer almaktadır. Bunun yanında TEMA Vakfı minik, yavru ve ortaokul TEMA programları ile çocuklarda ekolojik okuryazarlığı güçlendirmeyi amaçlamaktadır. Bunlar dışında öğretmenler de TÜBİTAK-4004 Doğa ve Bilim Okulları Projesi kapsamındaki doğa ve ekoloji temelli çevre eğitimi etkinliklerine katılarak, buradan elde edinilen bilgi, deneyim ve tecrübeleri sınıflarında öğrencilerine aktarabilme becerilerini geliştirebilmektedir.

Doğal alanların korunması ve sorunlarının önlenmesi için bir sistem içerisinde erken yaşta verilen eğitimin önemli olduğu birçok araştırmacı tarafindan bildirilmektedir (Barraza ve Walford, 2002; Lubomira, 2004; Kimble, 2014; Meier ve Sisk-Hilton, 2017; Otto ve Pensini, 2017; Tugurian ve Carrier, 2017; El-Batri ve ark., 2019; Ardoin ve Bowers, 2020). Ülkemizde doğa koruma ve eğitim konularında (Soykan, 2009; Yoleri, 2012; Altınbilek ve Karaardıç, 2019; Kurtuldu, 2019; Bakar ve ark., 2020; Topal ve ark., 2020) bilimsel çalışmalar yapılmakla beraber, eğitimin doğa koruma çalışmalarındaki etkinliğinin doğrudan tespit edilmesine yönelik çalışmalar yeterli değildir. İlköğretim öğrencileri ile yürütülen çalışmalar ağırlıklı olarak hayat bilgisi ve çevre bilgisi (Erdoğan, 2011; Birinci, 2013; Gök ve Afyon, 2015; Bakar ve ark., 2021) kapsamında yapılmaktadır. Dünyada bu konuda yapılan çalışmalar (Dietz ve Stern, 2002; Kimble, 2014; Tugurian ve Carrier, 2017) da sınırlı olmakla birlikte çocukların doğa ile ilişkilerinin sorgulandığı çalışmalar (Fien ve ark., 2001; Clover ve ark., 2013; Damerell ve ark., 2013; Edwards, 2015; Choe ve ark., 2020) dikkat çekmektedir.

Bu araştırmanın amacı ise Türkiye'de ortaokul düzeyinde yetersiz olduğu düşünülen doğa koruma eğitiminin uzman kişiler tarafından verilecek kısa süreli bir eğitim çalışması ile geliştirilebileceğini ortaya koymaktır. Ortaokul öğrencilerinin doğa koruma yaklaşımlarının belirlenmesi ve eğitime bağlı değişimlerinin değerlendirilmesi yanında doğa koruma eğitiminin küçük yaşlarda başlamasının öneminin de vurgulanması bir diğer hedeftir. Doğa koruma alanları ve planlaması konusunda deneyim ve yetkiye sahip peyzaj mimarlığı disiplini temelinde verilecek eğitim çalışmalarının öğrencilere katkı sağlayacağına inanılmaktadır. Çalışmadan elde edilen sonuçların doğa korumada özgün eğitimin önemini ortaya koyacağı, elde edilen verilerin başta Milli Eğitim Bakanlığı olmak üzere diğer ilgili kurumlarla paylaşılması sonucu bu konudaki eğitim çalışmalarının sistemli olarak yaygınlaşacağı düşünülmektedir.

\section{MATERYAL ve YÖNTEM:}

\subsection{Materyal}

$\mathrm{Bu}$ çalışmada doğa koruma yaklaşımlarında eğitime bağlı değişimlerin değerlendirilmesinde hedef grup olarak ortaokul öğrencileri seçilmiştir. Ortaokul dönemindeki 10-14 yaş grubu çocuklar ön ergenlik dönemi olarak tanımlanan erinlik dönemine denk gelmektedir. Bu dönemde çocuklar ergenlik psikolojisi gereğince kendileri için bir kimlik arayışına girmektedir. Çevresine olan ilginin daha çok arttığı bu dönemde çocuklara verilebilecek doğa koruma eğitiminin kişiliklerinin şekillenmesinde etkili olabileceği, gelecekte doğa koruma bilincine sahip bireylerin yetişmesine katkı sağlanabileceği düşünülmüş ve hedef grup ortaokul öğrencileri olarak belirlenmiştir. Ortaöğretim ders müfredatının incelenmesi sonucunda, doğa korumayla doğrudan ilgili bir ders bulunmadığı ancak bazı derslerde bu konuda yüzeysel bilgiler verildiği saptanmıştır. Uzmanlar tarafindan yönlendirilen ve özel konulara yoğunlaşan eğitim çalışmalarında, amaca yönelik olarak daha başarılı sonuçlar alındığı bilinmektedir.

Çalışmanın ana materyali Antalya ili Konyaaltı ilçesinde bulunan Ayten Çağıran Ortaokuludur. Antalya kent merkezinde Konyaaltı ilçesinde (12 ortaokul) 6.614, Muratpaşa ilçesinde (30 ortaokul) 19.943, Kepez ilçesinde (47 ortaokul) 26.290, Döşemealtı ilçesinde (17 ortaokul) 3.066, Aksu ilçesinde (26 ortaokul) 3.904 öğrenci olmak üzere 106 resmi ortaokulda 59.817 öğrenci eğitim-öğretimine devam etmektedir. Bu okulların öğrenci mevcudu ve okul özellikleri irdelenerek Konyaaltı ilçesinde bulunan Ayten Çağıran Ortaokulu çalışma alanı olarak belirlenmiştir. Çalışma alanı belirlendikten sonra anket ve eğitim çalışmalarının yapılabilmesi için Antalya İl Milli Eğitim Müdürlüğü'ne başvuru yapılmış ve gerekli izinler alınmıştır. Çalışmanın ana materyalleri, Ayten Çağıran Ortaokulu Öğrencileri, konuyla ilgili çalışmalar, anket formu ve eğitim sunumu olup, anket formlarından elde edilen verilerin değerlendirilmesinde IBM SPSS 20 programından yararlanılmıştır. 


\subsection{Yöntem}

Antalya kent merkezinde bulunan ortaokullarda doğa koruma yaklaşımlarının eğitimle değişiminin değerlendirilmesi amacıyla yapılan bu araştırma çalışma alanı ve ofis olmak üzere 2 yönde ve 4 aşamada yürütülmüştür. Araştırma yöntemi akış diyagramı Şekil 1'de sunulmuştur.

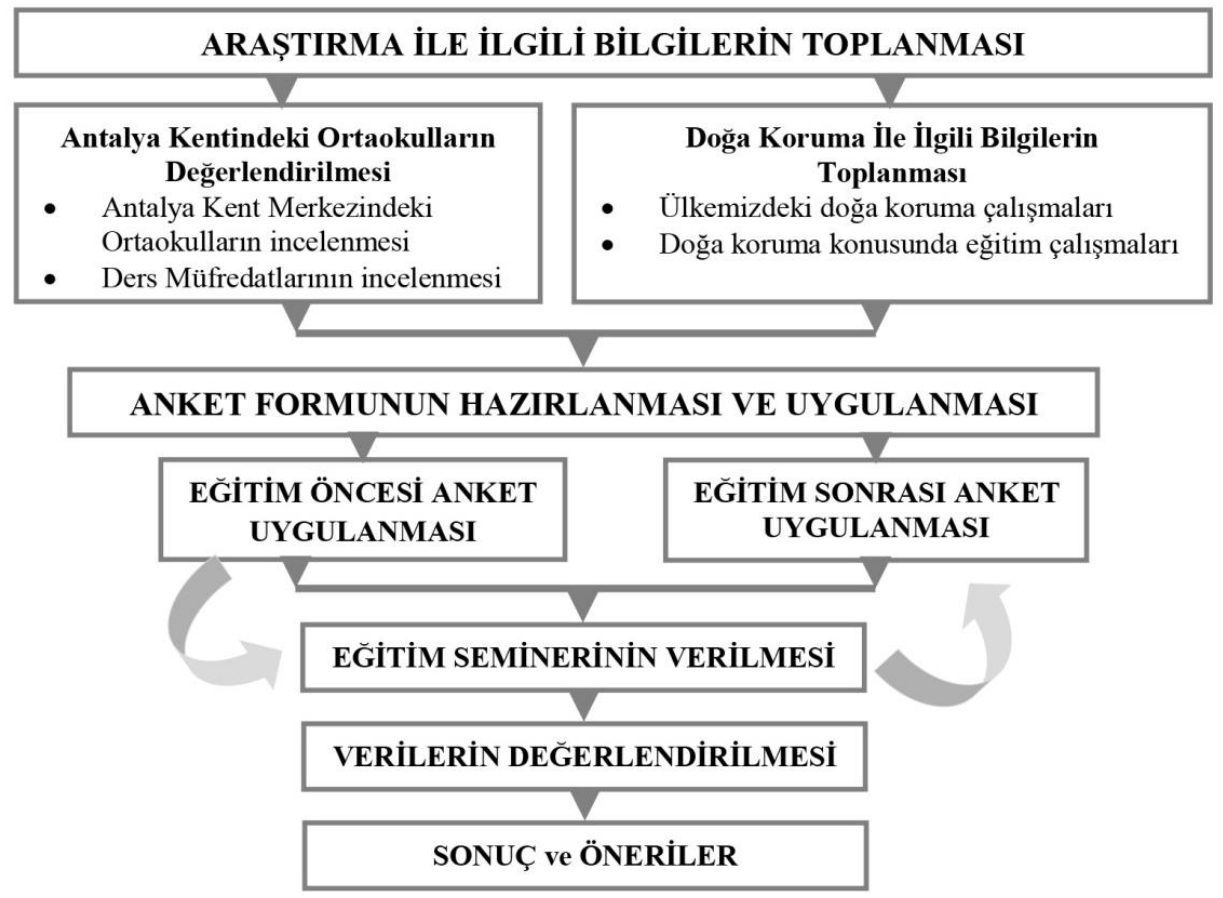

Şekil 1. Araştırma yöntemi akış diyagramı.

Araştırmanın ilk aşamasında Sencer ve Sencer (1978) tarafından önerilen, evrenin özellikleri hakkındaki bilgiye dayanılarak ve araştırmanın amacına göre evrenin temsil edildiği veya evrenin tipik bir örneği olduğu düşünülen bir alt grup ile çalışmanın yürütülmesi olarak tanımlanan amaçsal (monografik) örneklem seçim tekniği kullanılarak çalışmanın örneklemi belirlenmiştir. Böylece Antalya kent merkezindeki ortaokullar içerisinden bulunduğu konum, öğretmen sayısı, öğrenci sayısı ve okul branş durumu gibi kriterlere göre yapılan incelemeler sonucunda 852 öğrencisi bulunan Konyaaltı ilçesinde yer alan Ayten Çağıran Ortaokulu seçilmiştir. Türkiye'deki doğa koruma çalışmaları ile ilgili literatür taramasının ardından doğa koruma ve eğitim konusunda ülkemizde yapılmış olan akademik çalışmalar incelenmiştir.

Anket çalışması örneklem büyüklüğü ilgili evren büyüklükleri dikkate alınarak Baş (2001) tarafından önerilen, aşağıda formüle edilen, eşitlik kullanılarak \%5 hata payına göre hesaplanmıştır. Buna göre Antalya kent merkezinde yer alan 106 resmi ortaokuldaki öğrencileri (59.817) temsil edebilecek birey sayısı 382'dir. Ancak eksik, hatalı ve geçersiz anketlerin olabilme ihtimaline ve anketin güvenirliğini arttırmak amacıyla, Ayten Çağıran ortaokulunda 5. 6. 7. ve 8. sınıflarda öğrenim gören ve araştırmaya gönüllü olarak katılan tüm öğrencilere anket yapılarak örneklem oluşturulmuştur. Çalışma kapsamında geçerli 709 anket değerlendirmeye alınmıştır.

$\mathrm{n}=\frac{\mathrm{N} \cdot \mathrm{t}^{2} \cdot \mathrm{p} \cdot \mathrm{q}}{\mathrm{d}^{2} \cdot(\mathrm{N}-1)+\mathrm{t}^{2} \cdot \mathrm{p} \cdot \mathrm{q}} \quad \begin{aligned} & \mathrm{N}=\text { Evren büyüklüğü } \\ & \mathrm{p}=\text { İncelenen olayın görülüşs sılklı̆̆ } 1\end{aligned}$

$\mathrm{q}=$ İncelenen olayın görülmeme sıklığı $(\mathrm{q}=1-\mathrm{p})$

$\mathrm{t}=$ Belirli serbestlik derecesinde ve saptanan yanılma düzeyinde $\mathrm{t}$ tablosunda bulunan teorik değer (\%95 güven aralığı için t=1,96; \%99 güven aralığ için ise 2,59’dur) $\mathrm{d}=$ Olayın görülüş sıklığına göre yapılmak istenen sapma olarak simgelenmiştir.

$\mathrm{n}=$ Örnekleme alınacak birey sayısı 
Çalışmanın ikinci aşamasında ilk olarak öğrencilerin doğa koruma yaklaşımlarının belirlenmesi için anket formu hazırlanmıştır. Görüşme yoluyla sorgulamanın daha güvenli ve hızlı olması nedeniyle; evreni oluşturan bireylerin doğa ve koruma konusundaki yaklaşımlarının belirlenmesinde standart formlarla yerinde anket yöntemi kullanılmıştır.

Anket, öğrencilerin sosyo-ekonomik özellikleri, doğa ve koruma ile ilgili bilgileri ve tutumlarının belirlendiği iki bölümden oluşmaktadır. Hazırlanan anket formu öncelikle anket ve doğa koruma konusunda deneyimli uzmanların görüşleri doğrultusunda içerik, şekil, anlam ve değerlendirme açısından irdelenmiştir. Anketin uygulanacağ 1 ortaokulun ilgili öğretmenlerinin görüşleri alınarak öğrencilerin anlayacağı hale getirilmiştir. Her sınıf düzeyinden rastlantısal olarak 10 öğrenciye pilot uygulama yapılmış, elde edilen sonuçlara göre ankete son hali verilmiştir.

Ayten Çăğıran ortaokulunda 5. 6. 7. ve 8. sınıflarda öğrenim gören ve araştırmaya gönüllü olarak katılan tüm öğrencilere anket yapılmış, eksik, hatalı ve geçersiz anketlerin çıkarılması ile 709 anket değerlendirmeye alınmıştır. 1. tur ankete katılan öğrencilere 2. tur anket uygulanmıştır. İlk anket uygulaması doğa koruma eğitim semineri verilmeden önce yapılmıştır. Ardından öğrencilere aşağıdaki başlıklardan oluşan ve çalışma yapılan okulun rehberlik öğretmeninin görüşleri doğrultusunda şekillendirilen, tüm sınıfların anlayabileceği düzeyde hazırlanan bir seminer sunulmuştur. İkinci anket uygulaması ise eğitim seminer sunumunun ardından aynı anket formu kullanılarak yapılmışıtır.

- Doğa nedir?

- Doğayı oluşturan faktörler nelerdir?

- Doğa koruma nedir?

- Doğa neden korunmalıdır?

- Ülkemizdeki doğa koruma sınıfları nelerdir?

- Antalya'daki doğa koruma alanları nerelerdir?

- Doğa koruma konusunda çalışan kuruluşlar nelerdir?

- Ülkemizdeki doğa koruma alanlarının sorunları nerelerdir?

- Biz ne yapabiliriz?

Anket formlarından elde edilen veriler kodlanarak bilgisayar ortamına aktarılmış, IBM SPSS 20 programında değerlendirilmiştir. $\mathrm{Bu}$ aşamada frekans analizleri ve değişkenlerin karşılaştırılmasını sağlayan çapraz çizelgeler kullanılarak karşılaştırma analizleri yapılmış değişkenler arasındaki anlamlı farklılıklar ortaya konulmuştur. Cinsiyet ve yaş gruplarının vermiş oldukları yanıtlar arasındaki ilişkiyi ortaya koymak amacıyla ki-kare analizi yapılmıştır.

\section{BULGULAR:}

\subsection{Sosyo-Ekonomik Özellikler}

Ankete katılan 709 öğrencinin \%46,8'i erkek, \%53,2'si kız olup, bunların \%26,8'i 5. sınıf, \%21,7'si 6. sınıf, \%23,8'i 7. sınıf, $\% 27,6$ 's 1 ise 8 .sınıf öğrencisidir. Öğrencilerin anneleri ağırlıklı olarak ev hanımı $(\% 26,4)$, sağlık personeli $(\% 22,0)$ ve polis $(\% 18,6)$, babaları ise devlet memuru $(\% 24,1)$, polis $(\% 21,4)$ ve öğretmen $(\% 15,8)$ 'dir. Öğrencilerin $\% 85,9$ 'u apartman dairesinde, $\% 14,1^{\prime} \mathrm{i}$ ise müstakil evde yaşamaktadır. Öğrenciler okul saatleri dışında 1 . derecede mahalle $(\% 48,0), 2$. derecede park ve oyun alanları $(\% 24,4)$, 3. derecede diğer yerlerde (kapalı mekanlardaki oyun alanları ve oyun parkları) $(\% 34,4)$ oynamaktadırlar. Ortalamada ise en yüksek oranda mahalle $(\% 27,2)$ yer almaktadır (Çizelge 1).

Çizelge 1. Öğrencilerin okul saatleri dışında oynadıkları alanlar (\%).

\begin{tabular}{|c|c|c|c|c|}
\hline Oyun Alanı & 1. Derece & 2. Derece & 3. Derece & Ortalama \\
\hline Evin içerisinde & 29,5 & 22,1 & 20,2 & 23,9 \\
\hline Park ve oyun alanlarında & 19,4 & 24,4 & 10,3 & 18,0 \\
\hline Mahallede & 48,0 & 20,9 & 12,7 & 27,2 \\
\hline Site içerisinde & 1,1 & 24,1 & 22,4 & 15,8 \\
\hline Diğer & 2,0 & 8,5 & 34,4 & 14,9 \\
\hline Toplam & 100,0 & 100,0 & 100,0 & 100,0 \\
\hline
\end{tabular}




\subsection{Eğitim Sunumu Öncesi ve Sonrası Anketlerin Değerlendirilmesi}

Doğa ve koruma bilgisi ile ilgili soruların bulunduğu ikinci bölümde öğrencilere ilk olarak doğa ve koruma kelimelerinin onlar için ne ifade ettiği sorulmuş ve birer kelime ile açılamaları istenmiştir. Eğitim sunumu öncesi doğa kelimesi erkek öğrencilerin \%22,6'sı, kız öğrencilerin \%24,7'si için ormanı ifade ederken $(p<0,001)$, eğitim sunumu sonrası erkek öğrencilerin \%44'ü için ormanı, kız öğrencilerin \%31,0'1 için yaşamı ifade ettiği ve sonuçların istatistiksel olarak anlamlı olduğu görülmektedir $(p<0,001)$. Sunumda doğanın hayvanlar ve bitkiler için bir yaşam alanı olduğuna değinilmesi ile kız öğrencilerin sunum sonrası fikirlerini değiştirerek yaşam cevabını en yüksek verdikleri dikkat çekmektedir (Çizelge 2). Sınıf düzeyine bağlı olarak analiz sonuçlarına bakıldığında 8. sınıf öğrencileri sunum öncesi bu soruya $\% 21,4$ oranında bilmiyorum yanıtı verirken, sunum sonrasında en yüksek $\% 36,7$ oran ile çevre cevabını vermiş, bilmiyorum yanıtı verenlerin oranı \%2,0 ile sınırlı kalmıştır $(p<0,001)$. Çeliker ve Akar (2015) 2012-2013 öğretim yılında Burdur ilindeki farklı ortaokullarda öğrenim gören 238 ortaokul öğrencisinin "doğa" kavramına ilişkin sahip oldukları algıları metaforlar aracılığıyla belirlemişlerdir. Çalışmada öğrencilerin büyük çoğunluğu doğa kavramını yaşanılan yer ve yaşamın kaynağı olarak algıladıkları, doğanın önemi, değeri ve korunmasına ilişkin ifadeleri az sayıda kullandıkları saptanmıştır. Bu algıların sağlıklı olarak yapılandırılabilmesi için erken yaşlardan itibaren belirlenmesi, eksik ve yanlış öğrenmelerin ortadan kaldırılması, olumlu tutumlar gelişiminin sağlanması ve doğa dostu davranışların kazandırılmasının önemini ayrıca vurgulamışlardır.

Çizelge 2. Doğa sözcüğünün cinsiyet ve sınıflara göre anlamı (\%).

\begin{tabular}{|c|c|c|c|c|c|c|c|c|c|c|c|c|}
\hline \multirow{3}{*}{ DOĞA } & \multicolumn{4}{|c|}{ Cinsiyet } & \multicolumn{8}{|c|}{ Sınıf Düzeyi } \\
\hline & \multicolumn{2}{|c|}{ Erkek } & \multicolumn{2}{|c|}{ Kız } & \multicolumn{2}{|c|}{ 5.Sınıf } & \multicolumn{2}{|c|}{ 6.Sınıf } & \multicolumn{2}{|c|}{ 7.Sinıf } & \multicolumn{2}{|c|}{ 8.Sinıf } \\
\hline & Önce & Sonra & Önce & Sonra & Önce & Sonra & Önce & Sonra & Önce & Sonra & Önce & Sonra \\
\hline Çevre & 5,4 & 7,5 & 3,4 & 23,3 & 3,2 & 23,2 & 5,8 & 17,5 & 3,0 & 16,0 & 5,6 & 36,7 \\
\hline Huzur & 11,7 & 0,6 & 11,7 & 0,3 & 8,4 & 0,5 & 14,9 & 0 & 13,6 & 1,2 & 10,7 & 7,7 \\
\hline Orman & 22,6 & 44,0 & 26,5 & 18,0 & 28,9 & 31,6 & 25,3 & 24,7 & 26,0 & 27,8 & 18,9 & 35,2 \\
\hline Mutluluk & 16,3 & 15,7 & 16,2 & 15,6 & 23,2 & 33,2 & 18,2 & 16,9 & 17,2 & 13,0 & 7,1 & 0 \\
\hline Yaşam & 16,0 & 13,3 & 18,3 & 31,0 & 13,7 & 9,5 & 16,9 & 38,3 & 17,2 & 33,1 & 20,9 & 12,3 \\
\hline Yeşil & 13,0 & 1,5 & 11,9 & 4,0 & 14,2 & 2,1 & 9,7 & 1,3 & 9,5 & 1,2 & 15,3 & 6,1 \\
\hline Bilmiyorum & 15,1 & 17,5 & 13,4 & 7,7 & 8,4 & 0 & 9,1 & 1,3 & 13,6 & 7,7 & 21,4 & 2,0 \\
\hline Toplam & 100 & 100 & 100 & 100 & 100 & 100 & 100 & 100 & 100 & 100 & 100 & 100 \\
\hline$\chi^{2}$ & 37,904 & 299,982 & 80,451 & 191,263 & 64,726 & 120,926 & 28,364 & 92,935 & 36,320 & 87,184 & 35,143 & 95,458 \\
\hline p value & $<0,001$ & $<0,001$ & $<0,001$ & $<0,001$ & $<0,001$ & $<0,001$ & $<0,001$ & $<0,001$ & $<0,001$ & $<0,001$ & $<0,001$ & $<0,001$ \\
\hline
\end{tabular}

Koruma kelimesi eğitim sunumu öncesi cinsiyet ve sınıf düzeyine göre en yüksek oranda sahip çıkma şeklinde yanıtlanmıştır. Ancak bilmiyorum cevabını \%21,9 oranla en yüksek düzeyde veren 8 . sınıf öğrencilerinin yanıtları istatistiksel olarak anlamlı iken $\left(\chi^{2}=37,571 ; p<0,001\right)$, sunum sonrası bilmiyorum oranı $(\% 2,0)$ da dikkat çekmektedir $\left(\chi^{2}=72,900 ; p<0,001\right)$. Eğitim sunumu sonrası erkek öğrenciler ile 5. $(\% 36,8)$, 6. $(\% 24,0)$ ve 7 . sınıf $(\% 21,9)$ öğrencileri en yüksek oranla yardım yanıtını verirken, kız öğrenciler ile 8. sınıf öğrencileri birçok ifadeyi içinde toplayan diğer yanıtını vermişlerdir. Eğitim sunumunda koruma kelimesinin doğadaki birçok canlıya yardım etmek, onları korumak olduğunu öğrenen öğrencilerin cevaplarını yardım olarak değiştirdikleri düşünülmektedir (Çizelge 3).

Çizelge 3. Koruma sözcügünün cinsiyet ve sinıflara göre anlamı (\%).

\begin{tabular}{|c|c|c|c|c|c|c|c|c|c|c|c|c|}
\hline \multirow{3}{*}{ KORUMA } & \multicolumn{4}{|c|}{ Cinsiyet } & \multicolumn{8}{|c|}{ Sınıf Düzeyi } \\
\hline & \multicolumn{2}{|c|}{ Erkek } & \multicolumn{2}{|c|}{$\mathbf{K ı z}$} & \multicolumn{2}{|c|}{ 5.Sinıf } & \multicolumn{2}{|c|}{ 6.Sinıf } & \multicolumn{2}{|c|}{ 7.Sinıf } & \multicolumn{2}{|c|}{ 8.Sinıf } \\
\hline & Önce & Sonra & Önce & Sonra & Önce & Sonra & Önce & Sonra & Önce & Sonra & Önce & Sonra \\
\hline Güvenlik & 12,0 & 2,7 & 15,4 & 1,9 & 14,2 & 0 & 16,2 & 3,9 & 11,8 & 3,6 & 13,3 & 23,5 \\
\hline Dikkat & 15,1 & 9,6 & 14,3 & 27,9 & 7,4 & 23,2 & 16,2 & 19,5 & 20,1 & 14,2 & 15,8 & 19,9 \\
\hline Yardım & 2,1 & 32,5 & 2,9 & 11,7 & 2,1 & 36,8 & 3,9 & 24,0 & 3,6 & 21,9 & 1,0 & 4,1 \\
\hline Savunma & 12,3 & 15,1 & 14,3 & 6,9 & 16,8 & 0 & 13,0 & 7,8 & 11,8 & 14,8 & 11,7 & 19,9 \\
\hline Sahip Çıkma & 22,6 & 2,4 & 21,5 & 13,0 & 26,8 & 4,7 & 22,1 & 11,7 & 21,3 & 11,8 & 17,9 & 5,1 \\
\hline Diğer & 20,5 & 2,4 & 17,0 & 26,5 & 21,1 & 35,3 & 17,5 & 21,4 & 17,2 & 20,1 & 18,4 & 25,5 \\
\hline Bilmiyorum & 15,4 & 12,3 & 14,6 & 12,2 & 11,6 & 0 & 11,0 & 11,7 & 14,2 & 13,6 & 21,9 & 2,0 \\
\hline Toplam & 100 & 100 & 100 & 100 & 100 & 100 & 100 & 100 & 100 & 100 & 100 & 100 \\
\hline$\chi^{2}$ & 61,855 & 175,500 & 50,037 & 146,663 & 55,000 & 50,126 & 21,455 & 36,273 & 25,882 & 29,504 & 37,571 & 72,900 \\
\hline$p$ value & $<0,001$ & $<0,001$ & $<0,001$ & $<0,001$ & $<0,001$ & $<0,001$ & 0,002 & $<0,001$ & $<0,001$ & $<0,001$ & $<0,001$ & $<0,001$ \\
\hline
\end{tabular}


Öğrencilerden korunan alanlarda yaşanan sorunları önem derecesine göre sıralamaları istenmiştir. Eğitim sunumu öncesi 1.derecede $(\% 24,1)$ küresel ısınma, 2.derecede $(\% 17,8)$ hava kirliliği ve 3.derecede $(\% 27,8)$ çöpler öncelikli sorunlar arasında yer alırken, eğitim sunumu sonrası yapılan ankette 1 .derecede $(\% 54,7)$ küresel ısınma, 2. (\%25,1) ve 3.derecede $(\% 41,0)$ toprak kirliliği yer almıştır. Ağırlıklı ortalamaya göre ise eğitim sunumu öncesi yapılaşma $(\% 14,7)$, eğitim sonrası ise küresel ısınma $(\% 24,8)$ öncelikli sorun olarak görülmektedir (Çizelge 4). Öğrenciler tarafından verilen cevaplara bakıldığında $\% 24,1$ olan küresel ısınma cevabının eğitim sonrası $\% 54,7$ oranına çıması dikkat çekmektedir. Eğitim öncesi en önemli sorunlardan birinin çöpler olduğunu düşünen öğrenciler eğitim sunumu sonrası toprak kirliliğinin doğa koruma alanlarında yaşanan sorunlardan olduğunu öğrenmişlerdir.

Çizelge 4. Doğa koruma alanlarında yaşanan sorunların öncelik sıralaması (\%).

\begin{tabular}{lcccccccc}
\hline \multirow{2}{*}{ Sorunlar } & \multicolumn{2}{c}{ 1. Derece } & \multicolumn{2}{c}{ 2. Derece } & \multicolumn{2}{c}{ 3. Derece } & \multicolumn{2}{c}{ Ortalama } \\
\cline { 2 - 10 } & Önce & Sonra & Önce & Sonra & Önce & Sonra & Once & Sonra \\
\hline Yangın & 9,2 & 13,8 & 2,3 & 9,9 & 9,3 & 0,4 & 6,9 & 8,0 \\
\hline Küresel Isınma & 24,1 & 54,7 & 5,9 & 19,5 & 5,6 & 0,1 & 11,8 & 24,8 \\
\hline Toprak Kirliliği & 16,5 & 0,3 & 8,0 & 25,1 & 5,4 & 41,0 & 9,9 & 22,1 \\
\hline Su Kirliliği & 6,5 & 1,0 & 17,6 & 6,6 & 12,0 & 27,4 & 12,0 & 11,7 \\
\hline Erozyon & 0,1 & 0,4 & 2,0 & 0,6 & 3,2 & 4,5 & 1,7 & 1,8 \\
\hline Bitkilerin Zarar Görmesi & 1,7 & 2,0 & 5,1 & 4,5 & 12,4 & 14,7 & 6,4 & 7,1 \\
\hline Hava Kirliliği & 5,8 & 4,5 & 17,8 & 10,9 & 13,3 & 6,1 & 12,3 & 7,2 \\
\hline Hayvanların Zarar Görmesi & 17,1 & 4,2 & 16,9 & 0 & 2,3 & 4,8 & 12,1 & 3 \\
\hline Yapılaşma & 18,1 & 7,2 & 17,5 & 22,7 & 8,7 & 0,1 & 14,7 & 10 \\
\hline Çöpler & 1,0 & 11,8 & 6,9 & 0,3 & 27,8 & 0,8 & 11,9 & 4,3 \\
\hline Toplam & 100 & 100 & 100 & 100 & 100 & 100 & 100 & 100 \\
\hline
\end{tabular}

Doğanın anlamı ve önemi ile ilgili belirlenen ve aşağıda sunulan altı farklı görüşe öğrencilerin katılım düzeyi üç ölçekte sorgulanmıştır. Eğitim sunumu öncesi öğrenciler Görüş 5'e en yüksek düzeyde katılıyorum (ort.=1,05) yanıtı verirken, eğitim sonrası Görüş 1 ile Görüş 2'ye en yüksek düzeyde (ort.=1,01) katılıyorum şeklinde yanıt vermişlerdir (Çizelge 5). Eğitim sunumu sonrası Görüş 3, Görü̧s 4 ve Görüş 6'ya verilen yanıtların farklılık gösterdiği dikkat çekmektedir. Öğrencilere yöneltilen, doğanın anlamı ve önemi ile ilgili ifadeler değerlendirildiğinde eğitim sunumu sonrası verilen yanıtlara göre en büyük değişimin Görüş 4'e verilen yanıtlar arasında olduğu görülmektedir (Çizelge 5).

Çizelge 5. Doğanın anlamı ve önemi ile ilgili görüşler.

\begin{tabular}{|c|c|c|c|c|c|c|}
\hline \multirow{2}{*}{\multicolumn{2}{|c|}{ Görüş No İfade }} & \multicolumn{2}{|c|}{ Önce } & \multicolumn{2}{|c|}{ Sonra } & \multirow[t]{2}{*}{$\mathrm{n}$} \\
\hline & & Ort." & Std. D. & Ort. & Std. D. & \\
\hline Görüş 1 & Doğa tüm insanlığın ortak malıdır. Zarar veren onarmalıdır & 1,09 & 0,298 & 1,01 & 0,916 & 709 \\
\hline Görüş 2 & Doğa tüm insanlığın ortak malıdır. Satılmaz, kiralanmaz & 1,07 & 0,312 & 1,01 & 0,166 & 709 \\
\hline Görüş 3 & İnsan karışmazsa doğa bozulmaz & 1,72 & 0,804 & 1,06 & 0,267 & 709 \\
\hline Görüş 4 & Tarım dışında doğadan gelir elde ediliyorsa korunmayabilir & 2,37 & 0,758 & 1,90 & 0,878 & 709 \\
\hline Görüş 5 & Doğa gelecek için önemlidir. & 1,05 & 0,234 & 1,03 & 0,234 & 709 \\
\hline Görüş 6 & Ülkelerin doğanın korunmasından daha öncelikli sorunları vardır. & 2,07 & 0,714 & 1,97 & 0,903 & 709 \\
\hline
\end{tabular}

Doğanın anlamı ve önemi ile ilgili ifadelere verilen yanıtlar değerlendirildiğinde Görüş 1 'e verilen yanıtlarda eğitim sunumu öncesi ve sonrası cinsiyet ve sınıf düzeylerine göre istatistiksel olarak anlamlı farklılıklar görülmektedir. İfadeye eğitim sunumu öncesi erkeklerin \%91,6's1, kızların ise \%90,7'si katılıyorum yanıtı verirken, sunum sonras kararsızların da çoğunlukla katılıyorum yanıtı verdikleri görülmektedir. İfadeye 5. Sınıf öğrencileri sunum öncesi $\% 86,3$ oranla, 8. Sınıf ögrencileri ise $\% 94,4$ oranla katıllyorum yanıtı verirken, sunum sonrası her iki grubunda $\% 100,0$ oranla katılıyorum yanıtı vermeleri dikkat çekmektedir. Benzer şekilde Görüş 2 ve Görüş 5 'e eğitim öncesi ve sonrası cinsiyet ve sinıflara göre en yüksek düzeylerde kattllyorum yanıtı verilirken, bu yanıtların istatistiksel olarak anlamlı olduğu görülmektedir (Çizelge 6). Eğitim öncesi Görüş 4'e verilen yanıtlar tüm gruplarda çoğunlukla katılmıyorum şeklinde olup, eğitim sonrası katıllyorum şeklinde değişmekte ve yanıtların istatistiksel olarak anlamlı farklılıklar göstermesi dikkat çekmektedir. Ayrıca bu ifadeye eğitim sunumu öncesi kararsızım şeklinde verilen yanıtların oranında da düşüşler olduğu görülmektedir. Eğitim öncesi Görüş 6'ya kararsızım yanıtı verenlerin oranı oldukça yüksek iken, eğitim sonrası bu ifadeye verilen yanıtların farklılık göstermesi önem taşımaktadır $(p<0,001)$. 
Görüs 3'e eğitim öncesi katılmıyorum ve karasızım yanıtı veren katılımcıların eğitim sonrası tüm gruplarda yüksek oranla kattlyyorum şeklinde yanıt vermeleri eğitim çalışmalarının görüşler üzerinde etkili olduğunu ve yanıtların da istatistiksel olarak anlamlı olduğunu ortaya koymaktadır (Çizelge 6). Öğrenciler doğanın geleceğimiz için önemli olduğunu düşünmektedirler. Eğitim sonrası tüm grupların \%90-100 arası Görüşs 5'e katıllyorum cevabını vermeleri, eğitimin önemini açıkça ortaya koymaktadır. Doğanın anlamı ve önemi ile ilgili görüşlere katılımda kararsız kalma oranı eğitim sunumu sonrası azalmıştır.

Çizelge 6. Cinsiyet ve sınıflara göre doğanın anlamı ve önemi ile ilgili görüşlerin değerlendirilmesi (\%).

\begin{tabular}{|c|c|c|c|c|c|c|c|c|c|c|c|c|c|}
\hline \multirow{3}{*}{ GÖRÜŞ } & & \multicolumn{4}{|c|}{ Cinsiyet } & \multicolumn{8}{|c|}{ Sınıf Düzeyi } \\
\hline & & \multicolumn{2}{|c|}{ Erkek } & \multicolumn{2}{|c|}{ Kız } & \multicolumn{2}{|c|}{ 5.Sinıf } & \multicolumn{2}{|c|}{ 6.Sinıf } & \multicolumn{2}{|c|}{ 7.Sinıf } & \multicolumn{2}{|c|}{ 8.Sinıf } \\
\hline & & Önce & Sonra & Önce & Sonra & Önce & Sonra & Önce & Sonra & Önce & Sonra & Önce & Sonra \\
\hline \multirow{3}{*}{ Görüş 1} & $\mathrm{~A}^{*}$ & 91,6 & 98,8 & 90,7 & 99,5 & 86,3 & 100,0 & 91,6 & 98,7 & 92,3 & 96,8 & 94,4 & 100 \\
\hline & $\mathrm{B}$ & 8,1 & 1,2 & 9,0 & 0,5 & 12,6 & 0,0 & 8,4 & 1,3 & 7,7 & 3,2 & 5,6 & 0,0 \\
\hline & $\mathrm{C}$ & 0,3 & 0,0 & 0,3 & 0,0 & 1,1 & 0,0 & 0,0 & 0,0 & 0,0 & 0,0 & 0,0 & 0,0 \\
\hline$\chi^{2}$ & & 509,681 & 316,193 & 562,955 & 369,042 & 243,832 & - & 106,390 & 146,104 & 121,000 & 109,512 & 154,469 & - \\
\hline p value & & $<0,001$ & $<0,001$ & $<0,001$ & $<0,001$ & $<0,001$ & - & $<0,001$ & $<0,001$ & $<0,001$ & $<0,001$ & $<0,001$ & - \\
\hline \multirow{3}{*}{ Görüş 2} & $\mathrm{~A}$ & 94,6 & 98,8 & 94,2 & 98,1 & 94,2 & 100,0 & 93,5 & 97,4 & 96,4 & 94,4 & 93,4 & 100,0 \\
\hline & $\mathrm{B}$ & 4,2 & 0,3 & 4,0 & 1,9 & 2,6 & 0,0 & 5,2 & 1,3 & 3,6 & 4,8 & 5,1 & 0,0 \\
\hline & $\mathrm{C}$ & 1,2 & 0,9 & 1,9 & 0,0 & 3,2 & 0,0 & 1,3 & 1,3 & 0,0 & 0,8 & 1,5 & 0,0 \\
\hline$\chi^{2}$ & & 560,843 & 640,235 & 628,032 & 349,520 & 316,874 & - & 251,273 & 284,468 & 145,852 & 210,064 & 318,255 & - \\
\hline p value & & $<0,001$ & $<0,001$ & $<0,001$ & $<0,001$ & $<0,001$ & - & $<0,001$ & $<0,001$ & $<0,001$ & $<0,001$ & $<0,001$ & - \\
\hline \multirow{3}{*}{ Görüş 3} & $\mathrm{~A}$ & 46,7 & 97,6 & 53,3 & 90,2 & 51,1 & 100,0 & 55,2 & 92,9 & 51,5 & 88,0 & 44,4 & 92,1 \\
\hline & $\mathrm{B}$ & 29,8 & 2,4 & 25,5 & 9,0 & 25,8 & 0,0 & 26,6 & 5,8 & 26,6 & 11,2 & 30,6 & 7,9 \\
\hline & $\mathrm{C}$ & 23,5 & 0,0 & 21,2 & 0,8 & 23,2 & 0,0 & 18,2 & 1,3 & 21,9 & 0,8 & 25,0 & 0,0 \\
\hline$\chi^{2}$ & & 28,633 & 300,771 & 68,759 & 552,164 & 27,042 & - & 34,766 & 246,013 & 25,609 & 170,128 & 11,704 & 170,017 \\
\hline p value & & $<0,001$ & $<0,001$ & $<0,001$ & $<0,001$ & $<0,001$ & - & $<0,001$ & $<0,001$ & $<0,001$ & $<0,001$ & 0,003 & $<0,001$ \\
\hline \multirow{3}{*}{ Görüş 4} & $\mathrm{~A}$ & 17,8 & 41,9 & 16,4 & 45,3 & 12,6 & 39,5 & 19,5 & 51,9 & 20,7 & 47,2 & 16,3 & 40,0 \\
\hline & $\mathrm{B}$ & 27,7 & 7,8 & 29,4 & 34,5 & 24,2 & 23,2 & 26,6 & 20,1 & 28,4 & 24,8 & 34,7 & 20,8 \\
\hline & $\mathrm{C}$ & 54,5 & 50,3 & 54,1 & 20,2 & 63,2 & 37,4 & 53,9 & 27,9 & 50,9 & 28,0 & 49,0 & 39,2 \\
\hline$\chi^{2}$ & & 71,970 & 100,705 & 82,796 & 36,133 & 79,874 & 8,979 & 30,481 & 25,416 & 24,935 & 11,008 & 31,510 & 16,900 \\
\hline p value & & $<0,001$ & $<0,001$ & $<0,001$ & $<0,001$ & $<0,001$ & 0,011 & $<0,001$ & $<0,001$ & $<0,001$ & 0,004 & $<0,001$ & $<0,001$ \\
\hline \multirow{3}{*}{ Görüş 5} & $\mathrm{~A}$ & 95,8 & 98,8 & 94,4 & 95,2 & 95,3 & 97,9 & 94,8 & 94,2 & 92,9 & 92,8 & 96,9 & 100,0 \\
\hline & $\mathrm{B}$ & 4,2 & 0,3 & 5,0 & 4,0 & 3,7 & 2,1 & 5,2 & 3,2 & 7,1 & 5,6 & 3,1 & 0,0 \\
\hline & $\mathrm{C}$ & 0,0 & 0,9 & 0,5 & 0,8 & 1,1 & 0,0 & 0,0 & 2,6 & 0,0 & 1,6 & 0,0 & 0,0 \\
\hline$\chi^{2}$ & & 278,361 & 640,235 & 634,414 & 650,440 & 328,116 & 174,337 & 123,662 & 256,377 & 124,408 & 199,216 & 172,735 & - \\
\hline p value & & $<0,001$ & $<0,001$ & $<0,001$ & $<0,001$ & $<0,001$ & $<0,001$ & $<0,001$ & $<0,001$ & $<0,001$ & $<0,001$ & $<0,001$ & - \\
\hline \multirow{3}{*}{ Görüş 6} & $\mathrm{~A}$ & 19,6 & 41,9 & 23,9 & 41,9 & 17,4 & 37,4 & 26,0 & 46,1 & 24,3 & 44,0 & 20,9 & 41,7 \\
\hline & $\mathrm{B}$ & 48,5 & 25,0 & 48,3 & 12,7 & 45,8 & 0 & 50,6 & 11,0 & 49,7 & 16,0 & 48,0 & 39,2 \\
\hline & $\mathrm{C}$ & 31,9 & 33,1 & 27,9 & 45,4 & 36,8 & 62,6 & 23,4 & 42,9 & 26,0 & 40,0 & 31,1 & 19,2 \\
\hline$\chi^{2}$ & & 41,934 & 14,175 & 38,775 & 72,674 & 24,074 & 12,126 & 20,935 & 34,688 & 20,462 & 17,200 & 21,929 & 21,900 \\
\hline p value & & $<0,001$ & 0,001 & $<0,001$ & $<0,001$ & $<0,001$ & $<0,001$ & $<0,001$ & $<0,001$ & $<0,001$ & $<0,001$ & $<0,001$ & $<0,001$ \\
\hline
\end{tabular}

Doğanın korunmasının nedenleri ile ilgili belirlenen ve aşağıda sunulan beş farklı görüşe öğrencilerin katılım düzeyi sorgulandığında, eğitim sunumu öncesi Görüş 4'e en yüksek düzeyde (ort.=1,03) katıllyorum yanıtı verildiği görülmektedir. Eğitim sunumu sonrası ise en yüksek düzeyde katıliyorum yanıtı Görüş 1 ve Görüş̧ 3'e (ort.=1,03) verilmiştir (Çizelge 7).

Çizelge 7. Doğanın korunmasının nedenleri ile ilgili görüşler.

\begin{tabular}{|c|c|c|c|c|c|c|}
\hline \multirow{2}{*}{ Görüş No } & \multirow{2}{*}{ Iffade } & \multicolumn{2}{|c|}{ Önce } & \multicolumn{2}{|c|}{ Sonra } & \multirow[t]{2}{*}{$\mathrm{n}$} \\
\hline & & Ort. ${ }^{*}$ & Std. D. & Ort. & Std. D. & \\
\hline Görüş 1 & $\begin{array}{l}\text { İnsanlar bütün besin maddelerini doğadan karşılamaktadır. } \\
\text { Kaynaklarının azalmasını istemedikleri için doğayı korumalıdırlar }\end{array}$ & 1,21 & 0,433 & 1,03 & 0,231 & 709 \\
\hline Görüș 2 & Doğa bilimsel çalışmalar için birçok bilgi kaynağı barındırmaktadır & 1,32 & 0,507 & 1,05 & 0,228 & 709 \\
\hline Görüș 3 & Doğa anıtları doğanın ilgi çekici ve güzel örnekleridir & 1,12 & 0,348 & 1,03 & 0,196 & 709 \\
\hline Görüş 4 & Doğa gelecek için önemlidir & 1,03 & 0,188 & 1,34 & 0,752 & 709 \\
\hline Görüuş 5 & $\begin{array}{l}\text { Boş zamanlarımızda dinlenmek ve oyunlar oynamak için doğal } \\
\text { alanlara gideriz }\end{array}$ & 1,36 & 0,578 & 1,23 & 0,435 & 709 \\
\hline
\end{tabular}

1: Katıliyorum 2: Kararsızım 3: Katılmıyorum

Assessment of Educational Changes in Nature Conservation Approaches in the Example of Secondary School Students 
Eğitim öncesi ve sonrası cinsiyet ve sınıflara göre doğanın korunmasının nedenleri ile ilgili ifadelerden Görüş 1 , Görüş 2 ve Görüs 3'e tüm gruplar yüksek oranda kattlyyorum şeklinde görüş bildirmiş olup, yanttlar istatistiksel olarak anlamlıdır (Çizelge 8). Eğitim öncesi Görüss 4'e tüm gruplar en düşük oranla katılmıyorum şeklinde görüş bildirirken, eğitim sonrası katılımcıların ifadeye katılmıyorum şeklinde verdikleri yanıt oranının yüksek olduğu görülmektedir. Görüş 5'e eğitim öncesi kız $(\% 71,1)$ ve 8 . sınıf $(\% 61,7)$ öğrencilerinin katıllyorum şeklinde vermiş oldukları yanıtların oranı eğitim sonrasında artmıştır (\%88,9 kız; \%90,0 8. sınıf). İfadeye diğer grupların kararsızım şeklinde verdikleri yanıtlarda artış görülmesi ve katıllyorum şeklinde verilen yanıtlarda önemli bir değişikliğin olmaması dikkat çekmektedir $(p<0,001)$.

Çizelge 8. Cinsiyet ve sınıflara göre doğanın korunmasının nedenleri ile ilgili görüşlerin değerlendirilmesi (\%).

\begin{tabular}{|c|c|c|c|c|c|c|c|c|c|c|c|c|c|}
\hline \multirow{3}{*}{ GÖRÜŞ } & & \multicolumn{4}{|c|}{ Cinsiyet } & \multicolumn{8}{|c|}{ Sınıf Düzeyi } \\
\hline & & \multicolumn{2}{|l|}{ Erkek } & \multicolumn{2}{|c|}{$\mathbf{K a z}$} & \multicolumn{2}{|c|}{ 5.Sinif } & \multicolumn{2}{|c|}{ 6.Sinıf } & \multicolumn{2}{|c|}{ 7.Sinıf } & \multicolumn{2}{|c|}{ 8.Sinıf } \\
\hline & & Önce & Sonra & Önce & Sonra & Önce & Sonra & Önce & Sonra & Önce & Sonra & Önce & Sonra \\
\hline \multirow{3}{*}{ Görüş 1} & $\mathrm{~A}^{*}$ & 81,9 & 97,3 & 77,7 & 96,8 & 82,6 & 100 & 81,8 & 96,1 & 78,7 & 94,4 & 76,0 & 96,7 \\
\hline & $\mathrm{B}$ & 17,2 & 2,1 & 21,2 & 2,1 & 16,3 & 0 & 16,9 & 2,6 & 21,3 & 2,4 & 22,4 & 3,3 \\
\hline & $\mathrm{C}$ & 0,9 & 0,6 & 1,1 & 1,1 & 1,1 & 0 & 1,3 & 1,3 & 0,0 & 3,2 & 1,5 & 0,0 \\
\hline$\chi^{2}$ & & 365,970 & 611,211 & 357,204 & 683,782 & 214,432 & - & 168,519 & 273,091 & 55,675 & 209,776 & 173,582 & 209,067 \\
\hline p value & & $<0,001$ & $<0,001$ & $<0,001$ & $<0,001$ & $<0,001$ & - & $<0,001$ & $<0,001$ & $<0,001$ & $<0,001$ & $<0,001$ & $<0,001$ \\
\hline \multirow{3}{*}{ Görüş 2} & $\mathrm{~A}$ & 69,3 & 96,4 & 70,3 & 93,6 & 57,9 & 100,0 & 78,6 & 95,5 & 75,7 & 95,2 & 69,4 & 90,4 \\
\hline & $\mathrm{B}$ & 28,9 & 3,3 & 27,6 & 6,4 & 42,1 & 0,0 & 18,2 & 3,9 & 22,5 & 4,8 & 27,6 & 9,6 \\
\hline & $\mathrm{C}$ & 1,8 & 0,3 & 2,1 & 0,0 & 0,0 & 0,0 & 3,2 & 0,6 & 1,8 & 0,0 & 3,1 & 0,0 \\
\hline$\chi^{2}$ & & 229,614 & 594,404 & 268,398 & 287,111 & 4,737 & - & 146,974 & 267,675 & 147,633 & 102,152 & 132,286 & 156,817 \\
\hline p value & & $<0,001$ & $<0,001$ & $<0,001$ & $<0,001$ & 0,030 & - & $<0,001$ & $<0,001$ & $<0,001$ & $<0,001$ & $<0,001$ & $<0,001$ \\
\hline \multirow{3}{*}{ Görüş 3} & $\mathrm{~A}$ & 81,9 & 97,3 & 82,5 & 97,3 & 91,1 & 100 & 85,7 & 92,2 & 86,4 & 94,4 & 86,2 & 100,0 \\
\hline & $\mathrm{B}$ & 13,0 & 1,8 & 11,4 & 2,7 & 8,9 & 0 & 13,0 & 6,5 & 13,6 & 4,8 & 13,3 & 0 \\
\hline & $\mathrm{C}$ & 0,0 & 0,9 & 0,8 & 0 & 0,0 & 0 & 1,3 & 1,3 & 0,0 & 0,8 & 0,5 & 0 \\
\hline$\chi^{2}$ & & 182,277 & 611,139 & 509,623 & 338,061 & 128,084 & - & 193,299 & 240,831 & 89,521 & 210,064 & 251,520 & - \\
\hline$p$ value & & $<0,001$ & $<0,001$ & $<0,001$ & $<0,001$ & $<0,001$ & - & $<0,001$ & $<0,001$ & $<0,001$ & $<0,001$ & $<0,001$ & - \\
\hline \multirow{3}{*}{ Görüş 4} & $\mathrm{~A}$ & 97,0 & 67,8 & 95,8 & 95,0 & 97,9 & 65,3 & 96,8 & 78,6 & 95,9 & 78,4 & 94,9 & 100 \\
\hline & $\mathrm{B}$ & 3,0 & 1,5 & 4,2 & 0,3 & 2,1 & 0 & 3,2 & 1,9 & 4,1 & 2,4 & 5,1 & 0 \\
\hline & $\mathrm{C}$ & 0,0 & 30,7 & 0,0 & 4,8 & 0,0 & 34,7 & 0,0 & 19,5 & 0,0 & 19,2 & 0,0 & 0 \\
\hline$\chi^{2}$ & & 293,205 & 219,693 & 315,716 & 645,459 & 174,337 & 17,705 & 134,649 & 148,922 & 142,160 & 119,536 & 158,041 & - \\
\hline p value & & $<0,001$ & $<0,001$ & $<0,001$ & $<0,001$ & $<0,001$ & $<0,001$ & $<0,001$ & $<0,001$ & $<0,001$ & $<0,001$ & $<0,001$ & - \\
\hline \multirow{3}{*}{ Görüş 5} & $\mathrm{~A}$ & 64,8 & 63,0 & 71,1 & 88,9 & 64,2 & 65,3 & 74,0 & 74,0 & 74,6 & 72,0 & 61,7 & 90,0 \\
\hline & $\mathrm{B}$ & 29,5 & 36,7 & 24,4 & 10,6 & 32,1 & 34,7 & 21,4 & 25,3 & 21,9 & 26,4 & 30,1 & 10,0 \\
\hline & $\mathrm{C}$ & 5,7 & 0,3 & 4,5 & 0,5 & 3,7 & 0 & 4,5 & 0,6 & 3,6 & 1,6 & 8,2 & 0,0 \\
\hline$\chi^{2}$ & & 175,741 & 197,211 & 264,196 & 528,801 & 104,537 & 17,705 & 121,338 & 128,818 & 137,763 & 95,632 & 85,296 & 153,600 \\
\hline p value & & $<0,001$ & $<0,001$ & $<0,001$ & $<0,001$ & $<0,001$ & $<0,001$ & $<0,001$ & $<0,001$ & $<0,001$ & $<0,001$ & $<0,001$ & $<0,001$ \\
\hline
\end{tabular}

Öğrencilerin doğanın korunmaması durumunda ortaya çıkabilecek sorunlar konusundaki görüşleri aşağıda sunulan altı ifadeyle üç düzeyde sorgulanmıştır. Çizelge 9'a göre Görüş 1 ve Görüş 3 eğitim sunumu öncesi en yüksek (ort.=1,30) düzeyde katıllyorum yanıtı verilen ifadeler iken, sunum sonrası Görüş 1 en yüksek (ort.=1,01) düzeyde katıllyorum yanıtı verilen ifade olmuştur. Tüm ifadelerde eğitim sunumu sonrası katılım düzeyinin artması dikkat çekmektedir.

Çizelge 9. Doğanın korunmaması durumunda ortaya çıkabilecek sorunlar ile ilgili görüşler.

\begin{tabular}{|c|c|c|c|c|c|c|}
\hline \multirow{2}{*}{ Görüş No } & \multirow{2}{*}{ İfade } & \multicolumn{2}{|c|}{ Önce } & \multicolumn{2}{|c|}{ Sonra } & \multirow{2}{*}{$\mathrm{n}$} \\
\hline & & Ort. $^{*}$ & Std. D. & Ort. & Std. D. & \\
\hline Görüş 1 & İklim değişikliği ve küresel ısınma artacak & 1,30 & 0,580 & 1,01 & 0,129 & 709 \\
\hline Görüş 2 & Yoksulluk ve açlik artacak & 1,53 & 0,742 & 1,06 & 0,246 & 709 \\
\hline Görüş 3 & İyi içme suyu azalacak ve çok pahalı olacak & 1,30 & 0,664 & 1,07 & 0,261 & 709 \\
\hline Görüş 4 & Su için savaşlar çıkacak & 1,36 & 0,638 & 1,10 & 0,403 & 709 \\
\hline Görüş 5 & Çölleşme hızlanacak & 1,39 & 0,663 & 1,02 & 0,178 & 709 \\
\hline Görüş 6 & Bilimsel çalışmalar azalacak & 1,49 & 0,735 & 1,33 & 0,542 & 709 \\
\hline${ }^{*} 1:$ Katılly & um 2:Kararsızım 3: Katılmıyorum & & & & & \\
\hline
\end{tabular}


Doğanın korunmaması durumunda ortaya çıkabilecek sorunlar ile ilgili görüşlere tüm gruplardan katılımcıların sunum öncesi katılıyorum şeklinde vermiş oldukları yanıt düzeyleri, sunum sonrasında artış gösterirken, verilen yanıtlar arasında istatistiksel olarak anlamlı farklılıklar görülmektedir. Ancak bu artışın Görüş 6'da diğger ifadelere göre daha düşük oranda olduğu dikkat çekmektedir. İfadeye sunum öncesinde katılmıyorum şeklinde verilen yanıtların sunum sonrasında çoğunlukla kararsızım şeklinde değiştiği görülmektedir (Çizelge 10).

Çizelge 10. Cinsiyet ve sınıflara göre doğanın korunmaması durumunda oluşacak sorunlar ile ilgili görüşlerin değerlendirilmesi (\%).

\begin{tabular}{|c|c|c|c|c|c|c|c|c|c|c|c|c|c|}
\hline & \multicolumn{4}{|c|}{ Cinsiyet } & \multicolumn{8}{|c|}{ Sınıf Düzeyi } \\
\hline & & \multicolumn{2}{|l|}{ Erkek } & \multicolumn{2}{|c|}{ Kız } & \multicolumn{2}{|c|}{ 5.Sinıf } & \multicolumn{2}{|c|}{ 6.Sinıf } & \multicolumn{2}{|c|}{ 7.Sinıf } & \multicolumn{2}{|c|}{ 8.Sinıf } \\
\hline & & Önce & Sonra & Önce & Sonra & Önce & Sonra & Önce & Sonra & Önce & Sonra & Önce & Sonra \\
\hline \multirow{3}{*}{ Görüş 1} & $\mathrm{~A}^{*}$ & 78,0 & 97,3 & 73,5 & 99,2 & 68,9 & 100,0 & 76,6 & 96,8 & 78,7 & 94,4 & 78,6 & 100,0 \\
\hline & $\mathrm{B}$ & 17,2 & 2,7 & 19,1 & 0,8 & 26,3 & 0,0 & 14,3 & 3,2 & 14,2 & 5,6 & 16,8 & 0,0 \\
\hline & $\mathrm{C}$ & 4,8 & 0,0 & 7,4 & 0,0 & 4,7 & 0,0 & 9,1 & 0 & 7,1 & 0,0 & 4,6 & 0,0 \\
\hline$\chi^{2}$ & & 305,825 & 296,976 & 281,066 & 365,095 & 121,716 & - & 130,494 & 134,649 & 157,787 & 98,568 & 184,908 & - \\
\hline p value & & $<0,001$ & $<0,001$ & $<0,001$ & $<0,001$ & $<0,001$ & - & $<0,001$ & $<0,001$ & $<0,001$ & $<0,001$ & $<0,001$ & - \\
\hline \multirow{3}{*}{ Görüş 2} & $\mathrm{~A}$ & 66,0 & 96,4 & 57,8 & 91,0 & 62,1 & 100,0 & 59,7 & 96,1 & 56,8 & 92,8 & 66,8 & 87,1 \\
\hline & $\mathrm{B}$ & 21,4 & 3,6 & 24,9 & 9,0 & 13,7 & 0,0 & 26,6 & 3,9 & 30,8 & 7,2 & 23,5 & 12,9 \\
\hline & $\mathrm{C}$ & 12,7 & 0,0 & 17,2 & 0,0 & 24,2 & 0,0 & 13,6 & 0,0 & 12,4 & 0,0 & 9,7 & 0,0 \\
\hline$\chi^{2}$ & & 162,873 & 285,735 & 105,109 & 253,265 & 73,937 & - & 52,221 & 130,935 & 50,426 & 91,592 & 104,582 & 132,017 \\
\hline p value & & $<0,001$ & $<0,001$ & $<0,001$ & $<0,001$ & $<0,001$ & - & $<0,001$ & $<0,001$ & $<0,001$ & $<0,001$ & $<0,001$ & $<0,001$ \\
\hline \multirow{3}{*}{ Görüş 3} & $\mathrm{~A}$ & 81,3 & 97,0 & 80,4 & 89,7 & 83,2 & 97,4 & 80,5 & 88,3 & 80,5 & 88,8 & 79,1 & 95,0 \\
\hline & $\mathrm{B}$ & 8,7 & 2,7 & 6,9 & 10,3 & 7,9 & 2,6 & 6,5 & 11,7 & 5,9 & 10,4 & 10,2 & 5,0 \\
\hline & $\mathrm{C}$ & 9,9 & 0,3 & 12,7 & 0,0 & 8,9 & 0,0 & 13,0 & 0,0 & 13,6 & 0,8 & 10,7 & 0,0 \\
\hline$\chi^{2}$ & & 344,175 & 605,645 & 377,289 & 237,138 & 212,284 & 170,526 & 155,273 & 90,416 & 170,497 & 174,784 & 184,602 & 194,400 \\
\hline p value & & $<0,001$ & $<0,001$ & $<0,001$ & $<0,001$ & $<0,001$ & $<0,001$ & $<0,001$ & $<0,001$ & $<0,001$ & $<0,001$ & $<0,001$ & $<0,001$ \\
\hline \multirow{3}{*}{ Görüş 4} & $\mathrm{~A}$ & 74,1 & 95,5 & 70,6 & 90,5 & 54,7 & 100,0 & 72,1 & 94,2 & 77,5 & 91,2 & 84,7 & 87,1 \\
\hline & $\mathrm{B}$ & 18,4 & 4,5 & 19,6 & 3,2 & 33,7 & 0,0 & 16,2 & 5,8 & 14,8 & 8,0 & 10,7 & 3,3 \\
\hline & $\mathrm{C}$ & 7,5 & 0,0 & 9,8 & 6,4 & 11,6 & 0,0 & 11,7 & 0 & 7,7 & 0,8 & 4,6 & 9,6 \\
\hline$\chi^{2}$ & & 254,102 & 274,711 & 240,515 & 554,042 & 53,095 & - & 104,506 & 120,104 & 149,728 & 189,328 & 233,765 & 313,425 \\
\hline p value & & $<0,001$ & $<0,001$ & $<0,001$ & $<0,001$ & $<0,001$ & - & $<0,001$ & $<0,001$ & $<0,001$ & $<0,001$ & $<0,001$ & $<0,001$ \\
\hline \multirow{3}{*}{ Görüşs 5} & $\mathrm{~A}$ & 72,9 & 97,3 & 67,6 & 97,9 & 69,5 & 100,0 & 60,4 & 94,8 & 62,1 & 92,8 & 85,2 & 100,0 \\
\hline & $\mathrm{B}$ & 18,4 & 2,1 & 21,2 & 2,1 & 17,4 & 0,0 & 26,0 & 3,9 & 28,4 & 7,2 & 10,2 & 0,0 \\
\hline & $\mathrm{C}$ & 8,7 & 0,6 & 11,1 & 0 & 13,2 & 0,0 & 13,6 & 1,3 & 9,5 & 0 & 4,6 & 0,0 \\
\hline$\chi^{2}$ & & 238,416 & 611,211 & 205,406 & 345,679 & 112,179 & - & 54,247 & 262,026 & 72,154 & 91,592 & 238,235 & - \\
\hline p value & & $<0,001$ & $<0,001$ & $<0,001$ & $<0,001$ & $<0,001$ & - & $<0,001$ & $<0,001$ & $<0,001$ & $<0,001$ & $<0,001$ & - \\
\hline \multirow{3}{*}{ Görüş 6} & $\mathrm{~A}$ & 67,5 & 77,7 & 62,1 & 63,1 & 67,4 & 74,2 & 63,0 & 72,7 & 65,7 & 69,6 & 62,2 & 65,0 \\
\hline & $\mathrm{B}$ & 17,8 & 16,9 & 23,6 & 35,0 & 23,2 & 25,8 & 16,2 & 26,6 & 18,9 & 24,0 & 24,0 & 28,3 \\
\hline & $\mathrm{C}$ & 14,8 & 5,4 & 14,3 & 1,9 & 9,5 & 0,0 & 20,8 & 0,6 & 15,4 & 6,4 & 13,8 & 6,7 \\
\hline$\chi^{2}$ & & 174,548 & 300,747 & 144,960 & 212,790 & 104,379 & 44,547 & 61,416 & 123,130 & 79,893 & 79,792 & 76,786 & 125,200 \\
\hline p value & & $<0,001$ & $<0,001$ & $<0,001$ & $<0,001$ & $<0,001$ & $<0,001$ & $<0,001$ & $<0,001$ & $<0,001$ & $<0,001$ & $<0,001$ & $<0,001$ \\
\hline
\end{tabular}

Doğa koruma yaklaşımlarında eğitime bağlı değişimlerin değerlendirilmesi en çok farklılık beklenen sorulardan biri “ ̈Ülkemizdeki doğa koruma sınıfları nelerdir? bildiklerinizi yazınız'” sorusudur. Eğitim öncesi öğrencilerin hiç cevap veremedikleri bu soruda eğitim sonrası anket uygulamasına katılan öğrencilerin \%17,3'ü milli park, \%17,3'ü tabiat parkı, \%15,9'u doğal sit alanı, \%11,4'ü sulak alan, \%13,9'u tabiat anıtı, \%4,4'ü özel çevre koruma bölgesi, \%6,5'i tabiatı koruma alanı cevabını vermiş, \%13,2’si ise cevap verememiştir.

Antalya ilinde bulunan doğa koruma alanları sorulduğunda yine eğitim sunumu öncesi öğrencilerin \%97,9'u bilmiyorum derken, \%2,1'i Manavgat Şelalesi, \%0,1 ise Düden Şelalesi yanıtını vermişlerdir. Eğitim sunumunda Antalya'da bulunan bazı koruma alanları öğrencilere anlatılmıştır. Eğitim sonrası yapılan ankette cevaplar 10 ana başlık altında gruplandırılmıştır. Öğrencilerin \%18,8'i Kurşunlu Şelalesi, \%15,6’sı Köprülü Kanyon Milli Park1, \%14,2'si Manavgat Şelalesi, \%12,6’sı Beydağları (Olympos) Sahil Milli Parkı, \%10,5’i Kırkgöz Su Kaynakları, \%10,0’1 Altın Beşik Milli Parkı, \%4,0’1 Düden Şelalesi, \%3,8’ Termessos Milli Park1, \%1,5'i Karain Mağarası cevabını vermişler, \%8,9'u ise yanıt vermemiştir. 
Ülkemizde doğa koruma konusunda çalışma yürüten kurum ve kuruluşlar sorulduğunda eğitim sunumu öncesi öğrencilerin \%92,2'si bilmiyorum, \%4,9’u TEMA ve \%2,9'u ise ÇEVKO yanıtını vermişlerdir. Eğitim sunumu sonrası öğrencilerin \%21,1'i TEMA, \%16,3'ü Türkiye Tabiatını Koruma Derneği, \%15,0’1 ÇEVKO, \%12,0’1 Çevre ve Şehircilik Bakanlığı, \%10,2'si WWF ve \%8,6'sı TÜRÇEK yanıtı verirken, yalnız \%16,7'si bilmiyorum şeklinde yanıtlamışlardır.

Öğrencilere daha önce bir doğa koruma alanına gidip gitmedikleri sorulduğunda erkek öğrencilerin \%82,2’si, k1z öğrencilerin \%78,5'i daha önce bir koruma alanına gitmediklerini belirtmişlerdir. Ancak Antalya'da bulunan doğa koruma alanlarının anlatıldı̆̆ı eğitim sunumu sonrası soruya erkek öğrenciler \%46,1 oranında kız öğrenciler \%66,0 oranında doğa koruma alanlarına gittiklerini bildirmişlerdir. Antalya ilinde çok sayıda doğa koruma alanı bulunmasına rağmen, sunum öncesi verilen bu cevap öğrencilerin gittikleri alanın statüsü konusunda bilgi sahibi olmadıklarını düşündürmektedir. Çin'de 9-10 yaşındaki 1119 çocuğun katılımıyla, çocukların doğa ile iletişim kurmasında biyofili, biyofobi ve korumacı tutumun nasıl etkili olduğu anket aracılığıyla araştırılmıştır. Araştırma sonucunda doğayla olan temasın çocuklarda var olan doğa korkusunu azalttığı görülmüştür (Zhang ve ark., 2014). Ayrıca Otto ve Pensini (2017)'e göre çocuklarda doğa tabanlı bir çevre eğitimi çevresel bilgi, doğaya bağlılık ve ekolojik davranış ile birlikte ele alınmalıdır. 4 ve 6 . sınıf öğrencilerinin doğaya dayalı çevre eğitimine katılımı üzerine yürütülen çalışmada doğa tabanlı çevre eğitimine katılımın çevre bilgisi düzeyini arttırdığı sonucuna ulaşılmıştır. Benzer şekilde Yalçınkaya (2012), 6. sınıf öğrencilerinin doğal çevreye yakınlık düzeyi ile çevre sorunları farkındalık düzeyleri arasında pozitif yönde bir ilişki olmasına rağmen, bu ilişkinin düşük düzeyde olduğunu saptamıştır.

İnsanların doğa koruma alanlarında her istediklerini yapıp yapamayacakları sorulduğunda ise hem kızlar (\%69) hem de erkekler $(\% 66,9)$ en yüksek oranda hayır yanıtını vermişlerdir. Eğitim sunumu sonrası ise erkek öğrenciler \%68,4 oranında, kız öğrenciler \% 75,9 oranında hayır demişlerdir. Bu soruda eğitim sunumuna bağlı değişiklik öğrencilerin korunan alanlarda kişilerin keyfi davranamayacağına yönelik görüşlerini artırmıştır. Şahin ve Sert (2018), Antalya’da ortaokul 5, 6, 7 ve 8. sınıf öğrencilerinin biyolojik çeşitlilik konusundaki farkındalıklarını incelemişler, erkek öğrencilerin hayvanlarda farkındalıklarının daha yüksek olduğunu, bitkilerde ise bir farklılık olmadığını saptamışlardır. Bu çalışmada öğrencilerin evlerinin bahçeli olması ve hayvan beslemelerinin farkındalıkları üzerinde etkili olduğuna işaret edilmiştir.

\section{SONUÇ ve TARTIŞMA:}

Bu araştırmada Antalya/Konyaaltı ilçesinde bulunan Ayten Çağıran Ortaokulu 5. 6. 7. ve 8. sınıf öğrencilerinden 709 kişinin katılımı ile yapılan çalışmada, öğrencilere eğitim sunumu yapılmadan önceki bilgileri ile eğitim yapıldıktan sonrası bilgilerinin hangi yönde farklılık gösterdiği üzerinde durulmuştur. Anket yöntemi ile yapılan bu çalışmada verilen cevaplar IBM SPSS 20 programında cinsiyet ve sınıf düzeyi değişkenlerine bağlı olarak istatistiksel olarak değerlendirilmiştir. Öğrencilere eğitim sunumu öncesi ve sonrası yapılan anketlerle, uzman kişilerce verilen eğitimin etkinliği saptanmıştır. Sonuç olarak ortaokul öğrencileri örneğinde, uzman kişiler tarafindan verilen kısa süreli doğa koruma eğitimlerinin öğrenciler üzerinde etkili olduğu saptanmıştır. Eğitim sunumu sonrası doğanın anlamı ve önemi ile ilgili ifadelerde öğrencilerin görüşlerinin önemli düzeyde değişmesi dikkat çekmektedir. Doğanın tüm insanlığın ortak malı olarak görülmesi ve insanların doğanın bozulmasında önemli rol aldığ görüşü daha net bir şekilde ortaya konulmuştur. Ayrıca doğanın insanların besin ihtiyacını karşıladığı ve bilimsel çalışmalar için bilgi kaynağı olduğu görüşleri sunum sonrasında belirginlik kazanmıştır. Öğrenciler sunum sonrası doğanın korunması gerektiği görüşüne mutlak suretle katılım gösterirken, aksi durumda iklim değişikliği ve küresel 1sınmanın artacağ1, çölleşmenin hızlanacağı, iyi içme suyunun azalacağı ve bunlara bağlı olarak yoksulluk ve açlığın artacağı durumlarından endişe duyulması gerektiğini dile getirmişlerdir. Bununla birlikte eğitim sunumunun öğrencilerin doğa koruma yaklaşımlarına bakış açısı üzerinde etkili olduğu da dikkat çekmektedir. Sunum öncesi öğrenciler Antalya ilinde bulunan korunan alanlardan yalnızca Manavgat Şelalesi $(\% 2,1)$ ve Düden Şelalesini $(\% 0,1)$ sayarken, sunum sonrası 10 başlık altında koruma alanlarını sıralayabilmişlerdir. Bu durum doğa koruma konusunda çalışma yürüten kurum ve kuruluşlar sorulduğunda da görülmüştür. Benzer şekilde öğrencilerin daha önce ziyaret ettikleri alanların korunan alan statüsüne sahip olduğunu sunum sonrasında öğrendikleri verilen yanıtlardan anlaşılmaktadır. Tüm bunlar dikkate alındığında doğa koruma konusunda yapılan eğitim çalışmalarının öğrencilerin tutum, davranış ve bilinç düzeyleri üzerinde etkili olduğu, genel kültür ve eğitim düzeylerine katkı sağladığı yapılan çalışma ile kısmen ortaya konulduğu verilen yanıtların istatistiksel olarak anlamlı farklılıklar göstermesinden anlaşılmaktadır. 
Doğa ve doğa koruma konusunda içerdiği bilgiler açısından 2018-2019 yılı ortaöğretim yılı zorunlu derslerin içerikleri incelendiğinde tüm derslerde doğrudan bu yönde bilgi bulunmadığı belirlenmiştir. Ancak 5. sınıf Fen Bilimleri dersinde "İnsan ve Çevre" ünite başlı̆̆ altında yüzeysel olarak doğa ve doğada yaşanan sorunlar (su kirliliği, toprak kirliliği, hava kirliliği ve nükleer kirlilik); 5, 6, ve 7. sınıflarda Sosyal Bilimler dersinde ise "İnsanlar, Yerler ve Çevreler" dersi içeriğinde doğal faktörler (iklim, bitki örtüsü, yer şekilleri ve su kaynakları) ve beşeri faktörler (tarım, ticaret, sanayi, hayvancılık) anlatılmaktadır. Yolcu (2014)'e göre 1923-2013 yılları arasında ilköğretim birinci kademe hayat bilgisi ve fen ve teknoloji öğretim programlarında Hayat Bilgisi dersinde çevre eğitimi ile ilgili içerik en fazla Canlılar ünitesindedir. Derslerin işlenmesinde öğretmenlerin yaklaşımlarının önemli olduğu fen bilimleri, biyoloji, coğrafya ve sosyal bilgiler öğretmenlerin biyoçeşitlilik konusunun öğretimine ilişkin görüşlerin incelendiği bir çalışmada ortaya konulmuştur. Bulut ve Beşoluk (2019) tarafindan yapılan bu çalışmada öğretmenlerin biyoçeşitlilik konusunu işlerken farklı yöntem, teknik ve materyaller kullandıklarını ancak her öğretmenin bu yöntem, teknik ve materyalleri çeşitlendirme konusunda yeterince başarılı olamadığı saptanmıştır. Öğretmenler biyoçeşitliliğin verimli işlenebilmesi ve bu konuda bilinçli bir toplumun oluşabilmesi için gezi ve sergilerin düzenlenmesi, eğitim kamplarının yapılması, alanında uzman kişilerce okullarda seminer verilmesi, hayvanat bahçesi ve müze ziyaretleri gibi etkinliklerin daha çok yapılması ve önemsenmesi gerektiğine işaret etmişledir. Antalya'da yapılan bu çalışmada doğa koruma alanları konusunda peyzaj mimarlarının, çok yönlü yaklaşımları ile hazırlanan eğitim sunumunun, öğretmenler ile değerlendirilmesi ve uygulanması sonucu öğrencilere bu yönde olumlu katkı yaptığı ortaya konulmuştur. Eğitimde bu tür işbirliklerinin sürdürülebilir olmasının eğitimi olumlu etkileyeceği düşünülmektedir.

Türkiye'deki örgün eğitim programlarının doğa-çevre koruma durum tespitine yönelik çalışmalar bulunmakla birlikte eğitimde işbirliği ile elde edilen değişimin ortaya konulduğu çalışma sayısı sınırlıdır. Özellikle örgün eğitim programlarının doğa-çevre eğitimi konusundaki yetersizliklerinin giderilmesi ve doğa dostu bireylerin topluma kazandırılması bakımından doğa koruma eğitimlerinin daha küçük yaşlara indirilmesi bu konudaki en önemli noktadır. Gök ve Afyon (2015), ilköğretimin ikinci kademesindeki çevre eğitiminin gerekli katkıyı sağlamadığı ve bunun nedenlerinin ayrıntılı bir şekilde araştırılması gerektiğini vurgulamışlardır. Sağır ve ark. (2008), ilköğretim öğrencilerinin çevre bilgisi ve tutumlarının öğrenim gördükleri okullarda aldıkları eğitimle farklılaştı̆̆ını belirtmektedirler. Kalender (2010), Türkiye'de yapılan doğa eğitimleri değerlendirdiği çalışmasında çeşitli meslek gruplarının katılımı ile yapılan çalışmaların önemli olduğunu ve bu eğitimler ile doğaya saygıll, onu anlayabilen, katılımcı, sorunların farkında olan ve çözüm üretebilen bireylerin yetiştirilebileceğini ifade etmiştir. Bu çalışmada doğa ve çevre koruma konusunda uygulamada etkin çalışan peyzaj mimarlarının verdiği çok yönlü eğitimin farklı sinıflarda okuyan, kız ve erkek öğrenciler üzerinde olumlu etki yaptığı ortaya konulmuştur. Özellikle bilgi düzeyine bağlı sorulara verilen yanıtların eğitim öncesi ve sonrası karşılaştırmalarında dikkate değer farklılıklar saptanmıştır. Doğa koruma çalışmalarında insan ve doğa arasındaki ilişkileri irdeleyen ve bunlar arasında bir köprü oluşturan peyzaj mimarlarının, anket ve eğitim çalışmaları sırasında öğrencilerin yoğun ilgisine dayanılarak, verilen eğitim çalışmasında etkin olduğu düşünülmektedir.

Doğayı korumaya karşı duyarlı bireyler yetiştirebilmek için;

- Eğitim-öğretim sürecinin her aşamasında doğa ve doğa koruma ile ilgili uzmanları tarafindan yürütülecek derslere eğitim müfredatında yer verilmesi,

- Eğitim-öğretim müfredatına dahil edilecek yaz okulu niteliğinde doğa eğitimi programlarının uygulanması,

- Okul dışından doğa ve doğa koruma konusunda uzman kişilerce belirli sürelerde seminerler düzenlenmesi,

- Doğa koruma alanlarına uzmanlar eşliğinde teknik geziler düzenlenmesi,

- Doğa koruma bilincini artmaya yönelik okul içi ve çevresinde öğrencilere (temizlik, bitki bakımı ve yetiştirme, sokak hayvanı sahiplenilmesi) sorumlulukların erken yaştan itibaren verilmesi önem taşımaktadır.

Doğayı korumaya karşı duyarlı bireyler yetiştirebilmek temeli aile ve okulda atılan eğitimle mümkündür. Bu çalışmada doğa koruma çalışmaları konusunda devamlılığın sağlanabilmesi için bilinçli insan faktörünün önemi yapılan eğitim çalışmaları ile ortaya konmuştur. Sonuç olarak doğa koruma bilincine sahip bireyler yetiştirmek için erken ergenlik dönemlerinde ve kendi kimlik arayışlarını tamamladıkları yıllarda, ortaokul öğrencilerine verilecek doğa koruma eğitiminin daha yararlı ve kalıcı olacağı, uzun vadede daha bilinçli bireyler yetiştirmek amacıyla doğa koruma eğitimine ortaöğretim ders müfredatında daha çok yer verilmesinin ve öğrencilerin bu konuda çok yönlü eğitim almasının sağlanması için doğa korumaya çok yönlü bakılması açısından başta peyzaj mimarları olmak üzere, ilgili meslek gruplarından yararlanılmasının fayda sağlayacağı düşünülmektedir. 


\section{Etik Standart ile Uyumluluk}

Çıkar Çatışması: Yazarlar herhangi bir çıkar çatışmasının olmadığını beyan eder.

Etik Kurul İzni: Bu çalışmada kullanılan anket formu, Akdeniz Üniversitesi Fen ve Mühendislik Bilimleri Bilimsel Araştırma ve Yayın Etiği Kurulu tarafından (01.03.2018 tarih ve 04/2 sayı numarası ile) katılanların oy birliği ile etik olarak uygun bulunmuştur.

Teşekkür: Ayten Çağıran Ortaokulu yöneticileri, öğretmenleri ve öğrencilerine çalışmaya katkıları için teşekkür ederiz.

\section{KAYNAKÇA:}

Altınbilek, G., \& Karaardıç, H. (2019). Kuş Halkalama İstasyonlarının Çevre Eğitimi Açısından Önemi. Doğanın Sesi, (4), 75-82.

Ardoin, N. M., \& Bowers, A. W. (2020). Early childhood environmental education: A systematic review of the research literature. Educational Research Review, 100353.

Bakar, F., Çağrı, A. V. A. N., Şeker, F., \& Aydinli, B. (2020). Plant and Animal Awareness in Nature Education Perspectives: Where is Blindness?. International Electronic Journal of Environmental Education, 10 (2), 122-135.

Bakar, F., Avan, Ç., Aydınlı, B., Şeker, F., \& Turgut, B. (2021). Okul Dışı Öğrenme Ortamı Olarak Doğa Eğitiminin Çevre Bilgisi ve Tutum Üzerine Etkisi . Akademia Doğa ve İnsan Bilimleri Dergisi, 7 (1) , 1-18

Barraza, L., \& Walford, R. A. (2002). Environmental education: A comparison between English and Mexican school children. Environmental Education Research, 8(2), 171-186.

Baş, T. (2001). Anket: anket nasıl hazırlanır?: anket nasıl uygulanır?: anket nasıl uygulanır?. Seçkin yayıncılık.

Birinci, O. (2013). İlkokul 3. sınıf hayat bilgisi dersine yönelik geliştirilen doğa eğitimi etkinliklerinin öğrencilerin doğa algılarına etkisie (Master's thesis, Recep Tayyip Erdoğan Üniversitesi/Sosyal Bilimler Enstitüsü/Sınıf Öğretmenliği Anabilim Dalı).

Bulut, M., \& Beşoluk, Ş. (2019). Fen Bilimleri, Biyoloji, Coğrafya ve Sosyal Bilgiler Öğretmenlerinin Biyoçeşitlilik Konusunun Öğretimine İlişkin Görüşleri. Journal of Interdisciplinary Education: Theory and Practice, 1(2), 133-153.

Campbell, C., \& Robottom, I. (2004). Environmental education: Appropriate vehicle for science education? Teaching Science, 50(2), 18-23.

Choe, J. H., Kim, C. H., \& Ri, G. H. (2020). An investigation on the environmental knowledge and attitudes of senior middle school students in the Democratic People's Republic of Korea. International Research in Geographical and Environmental Education, 29(2), 146-162.

Clover, D. E., Jayme, B. D. O., Hall, B. L., \& Follen, S. (2013). The nature of transformation: Environmental adult education (Vol. 11). Springer Science \& Business Media.

Çeliker, H.D., \& Akar, A., 2015. Ortaokul Öğrencilerinin Doğaya İlişkin Metaforları. Ahi Evran Üniversitesi Kırşehir Eğitim Fakültesi Dergisi (KEFAD) 16 (2), 101-119.

Damerell, P., Howe, C., \& Milner-Gulland, E. J. (2013). Child-orientated environmental education influences adult knowledge and household behaviour. Environmental Research Letters, 8(1), 015016.

Dietz, T., \& Stern, P. (2002). New tools for environmental protection. Education, Information and Voluntary Measures.

Edwards, J. (2015). Socially-critical environmental education in primary classrooms: The dance of structure and agency (Vol. 1). Springer.

El-Batri, B., Alami, A., Zaki, M., \& Nafidi, Y. (2019). Extracurricular Environmental Activities in Moroccan Middle Schools: Opportunities and Challenges to Promoting Effective Environmental Education. European Journal of Educational Research, 8(4), 1013-1028.

Erdogan, M. (2011). The Effects of Ecology-Based Summer Nature Education Program on Primary School Students' Environmental Knowledge, Environmental Affect and Responsible Environmental Behavior. Educational Sciences: Theory and Practice, 11(4), 2233-2237.

Fien, J., Scott, W., \& Tilbury, D. (2001). Education and conservation: Lessons from an evaluation. Environmental education research, 7(4), 379-395. 
Gök, E., \& Afyon, A. (2015). İlköğretim Öğrencilerinin Çevre Bilgisi ve Çevresel Tutumları Üzerine Alan Araştırması. Türk Fen Eğitimi Dergisi, 12 (4), 77-93.

Gruenewald, D. A. (2004). A Foucauldian analysis of environmental education: Toward the socioecological challenge of the earth charter. Curriculum Inquiry, 34(1), 71-107. https://doi.org/10.1111/j.1467-873x.2004.00281.x.

Istiqomah, I., Suwondo, S., \& Firdaus, L. N. (2020). Environmental Education in Forming Attitudes of Environmental Care for Students. Journal of Educational Sciences, 4(1), 200-211.

Kalender, Ç. (2010). Türkiye'de yapılan doğa eğitimlerinin değerlendirilmesi (Kaçkar Dă̆ları Milli Parkı örneği) (Master's thesis, Artvin Çoruh Üniversitesi).

Kimble, G. (2014). Children learning about biodiversity at an environment centre, a museum and at live animal shows. Studies in educational evaluation, 41, 48-57.

Kurtuldu A. (2019). “Ekoloji Temelli Eğitimlerin Ortaokul Öğrencilerinin Ekolojik Ayak İzi Farkındalığına Etkisi”. Yüksek lisans tezi, Akdeniz Üniversitesi Eğitim Bilimleri Enstitüsü, Antalya.

Lubomira, D. (2004). Environmental education at pre-school. International Research in Geographical \& Environmental Education, 13(3), 258-263.

Meier, D., \& Sisk-Hilton, S. (2017). Nature and environmental education in early childhood. The New Educator, 13(3), 191-194.

Monroe, M. C., Andrews, E., \& Biedenweg, K. (2008). A framework for environmental education strategies. Applied Environmental Education \& Communication, 6(3-4), 205-216.

Norris, I. E., \& Juliet, U. D. (2016). Impact of environmental education on the knowledge and attitude of students towards the environment. International Journal Of Environmnetal \& Science Education, 11(12), 5367-5375.

Otto, S., \& Pensini, P. (2017). Nature-based environmental education of children: Environmental knowledge and connectedness to nature, together, are related to ecological behaviour. Global Environmental Change, 47, 88-94.

Reis, G., \& Guimaraes-Iosif, R. (2012). The death and life of a school-based environmental education and communication program in Brazil: Rethinking educational leadership and ecological learning. Applied Environmental Education and Communication, 11(3-4), 123-132.

Reis, G., Scott, J., \& Freiman, M. (2018). Environmental education: Nurturing a relationship with everything, everywhere. In International perspectives on the theory and practice of environmental education: A reader (pp. 1-15). Sağır, Ş. U., Aslan, O., \& Cansaran, A. (2008). İlköğretim Öğrencilerinin Çevre Bilgisi ve Çevre Tutumlarının Farklı Değişkenler Açısından İncelenmesi. Ilkogretim Online, 7(2).

Sencer, M., \& Sencer, Y. (1978). Toplumsal araştırmalarda yöntembilim. Türkiye ve Orta Doğu Amme İdaresi Enst.

Soykan, A. (2009). Ecology-based environmental education in years between 1999-2008 in protected areas of Turkey: Aims and objectives, problems and suggestions. Procedia-Social and Behavioral Sciences, 1(1), 1704-1708.

Şahin, Ü.G., \& Sert, H., (2018). İlköğretim Öğrencilerinin Biyoçeşitlilik Konusundaki Farkındalıklarının İncelenmesi. Kastamonu Ĕ̈itim Dergisi, 26 (3), 801-812.

Topal, M., Yıldırım, E. G., \& Önder, A. N. (2020). Use of educational films in environmental education as a digital learning object. Journal of Education in Science Environment and Health, 6(2), 134-147.

Tugurian, L. P., \& Carrier, S. J. (2017). Children's environmental identity and the elementary science classroom. The Journal of Environmental Education, 48(3), 143-153.

Yalçınkaya, E. (2012). İlköğretim 6. Sınıf Öğrencilerinin Çevre Sorunları Farkındalık Düzeyleri. Marmara Coğrafya Dergisi, (25), 137-151.

Yolcu, O. (2014). Cumhuriyetten (2013) günümüze (2013) ilköğretim birinci kademe hayat bilgisi ve fen ve teknoloji ögretim programlarının" çevre eğitimi" açısından incelenmesi (Master's thesis, Adnan Menderes Üniversitesi).

Yücel, M. (2010). Doğa Koruma. Çukurova Üniversitesi Ziraat Fakültesi Peyzaj Mimarlığı Bölümü Ders Kitabı, Çukurova Üniversitesi Ziraat Fakültesi Genel Yayın No: 265, Ders Kitapları Yayın No: A-85,

Yoleri, S. (2012). Children and the environment: creating environmental awareness among preschool children. Buca Faculty of Education Journal, (34), 100-111.

Zhang, W., Goodale, E., \& Chen, J. (2014). How contact with nature affects children's biophilia, biophobia and conservation attitude in China. Biological Conservation, 177, 109-116. 